\title{
EU Advanced Study Course: Holocene Climate Reconstuction
}

\author{
LONDON, UK, JUNE 15-25, 1998
}

\section{Expert Lectures}

\section{Forcing mechanisms and climate simulations in the Holcene \\ Paul Valdes (Reading University) \\ Jonathon Overpeck (National \\ Geophysical Data Center) \\ Instrumental and documentary records}

Phil Jones (University of East Anglia) Roy Thompson (University of Edinburgh) Peter Brimblecombe (University of East Anglia)

\section{Chronologies and temporal time} scales

Mike Baillie, (Queens University, Belfast) Valerie Hall (Queens University, Belfast) Jonathan Pilcher (Queens University, Belfast) Ingemar Renberg (Umea University)

Proxy archives used in Holocene climate reconstructions

Keith Barber (Southampton University) Julie Cole (University of Colorado) Sheri Fritz (LeHigh University) Stein-Erik Lauritzen (University of Bergen) Mark Maslin (University College London) John Matthews (University of Wales) David Peel (British Antarctic Survey)

Proxy methods and climate reconstruction

John Birks (University of Bergen) Steve Brooks (Natural History Museum) Sheri Fritz (LeHigh University) Joel Guiot (University of Marseilles) Jonathan Holmes (Kingston University) Phil Jones (University of East Anglia) Andy Lotter (University of Bern)

\section{Appplications of Holocene climate research in PEP III}

Keith Bennett (Cambridge University) Atte Korhola (Helsinki University) Henry Lamb (Aberystwyth University) Frank Sirocko (University of Kiel) Tony Stevenson (Newcastle University) Lucia Wick (University of Bern)

Human society and climate history in PEP III

Fekri Hassan (University College London) Steve Shennan (University College London) Paul Sinclair (University of Uppsala) Holocene climate research in other regions: PEP I, PEP II, CAPE and Antarctica

John Dodson (Perth University) Viv Jones (University College London) Glen Macdonald (University of Colorado) Vera Markgraf (University of Colorado)
The Environmental Change Research Centre, University College London, hosted an eleven day Advanced Study Course entitled "Holocene Climate Reconstruction", earlier this year from June 15th to 25th. The course was funded by the European Union, and 30 European $\mathrm{PhD}$ and Masters candidates, selected by a scientific panel, were invited to attend with all accommodation and food paid.

Classes were designed to follow closely the scientific agenda set out by the IGBP Past Global Changes (PAGES) program, and the Executive Director of PAGES, Prof. Frank Oldfield, gave the opening paper. The course was designed to strengthen the European science base in paleoclimatic research well into the next century, and consisted of a series of lectures, followed by discussions and computer-based practicals. The course thus provided a unique forum for young European scientists to hear some 36 international experts give in depth overviews of their research field, and discuss the latest research findings and state of the art techniques (see "Expert Lectures").

The students prepared posters which were displayed throughout the meeting, and they also presented short papers (20 minutes) on their research to the rest of the group. The overall quality of the posters and presentations was outstanding, with many at a level comparable with international meetings. Three poster and three presentation winners were however, selected on the basis of quality of presentation, clarity, scientific input and stage of career (see "Winners").

\section{Anson W. Mackay}

Environmental Change Research Centre, University College London, UK

amackay@geog.ucl.ac.uk

http://www.geog.ucl.ac.uk/ecrc/advanced.htm

\section{Winners}

\section{Posters}

\section{Anna Agusti-Panadera}

(Edinburgh University, UK)

Reconstructing 200 years of climate

change at remote alpine lakes in Europe

\section{Sonja Hausmann}

(University of Berne, Switzerland) High-resolution study of the last centuries in the laminated sediments of subalpine Seebergsee (Switzerland)

\section{Christin Jensen}

(Tromso University, Norway)

Reconstructions of Holocene forest-line displacements and climate in NorthNorway

\section{Presentations}

\section{Bodo Bookhagen}

(Potsdam University, Germany)

Water balance model of a landslide dammed lake in the Andes of NW Argentina $\left(26^{\circ} \mathrm{S}, 66^{\circ} \mathrm{W}\right)$

\section{Graziella Bozzano}

(Barcelona University, Spain)

A case study of paleoclimate variability deduced from the marine sedimentary records

\section{Jorijntie Hendericks}

(ETH-Zentrum, Switzerland)

Holocene coccolith assemblages and morphology in the eastern boundary current system (NW Africa)
Full references for the reports and papers published in this newsletter can be obtained from the respective authors

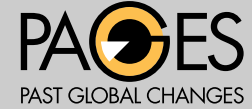

PAGES International Project Office Bärenplatz 2

$\mathrm{CH}-3011$ Bern, Switzerland Tel: +41313123133 Fax: +41313123168 e-mail: pages@pages.unibe.ch http:// www.pages.unibe.ch Editors: Frank Oldfield and Keith Alverson Layout: Niklaus Schranz 